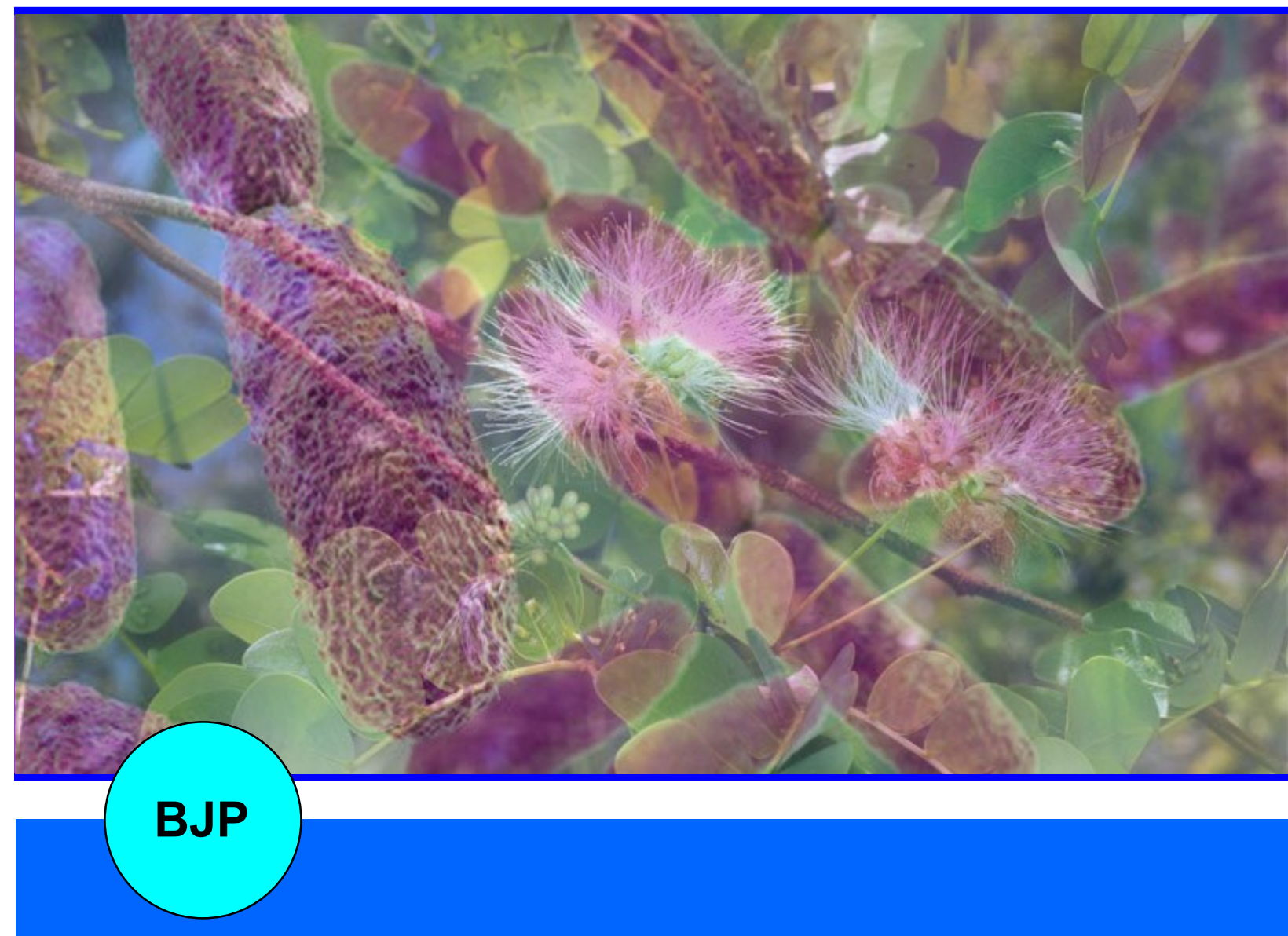

Bangladesh Journal of Pharmacology

Research Article

Antibacterial activity of Cathormion umbellatum 


\title{
Antibacterial activity of Cathormion umbellatum
}

\author{
Surachai Rattanasuk², Rujirek Boongapim² and Tannatorn Phiwthong1
}

${ }^{1}$ Department of Science and Technology, Faculty of Liberal Arts and Science, Roi Et Rajabhat University, Selaphum, Roi Et 45120, Thailand; ' 2 Faculty of Education, Roi Et Rajabhat University, Selaphum, Roi Et 45120, Thailand.

\begin{tabular}{|c|}
\hline Article Info \\
\hline Received. $\quad 15$ Mav 2021 \\
\hline $\begin{array}{ll}\text { Received: } & \text { 15 May } 2021 \\
\text { Accepted: } & \text { 12 July 2021 }\end{array}$ \\
\hline $\begin{array}{ll}\text { Accepted: } & \text { 12 July } 2021 \\
\text { Available Online: } & \text { 13 July 2021 }\end{array}$ \\
\hline DOI: 10.3329/bjp.v16i3.53420 \\
\hline
\end{tabular}

\begin{abstract}
The aim of this study was to determine the antibacterial activity of Cathormion umbellatum extracts against seven antibiotic-resistant bacteria. The pods, leaves and branches of C. umbellatum were extracted with ethanol and methanol. The disc diffusion assay was used to screen the antibacterial activity and broth microdilution and colorimetric assay were used to measure the minimum inhibitory concentration (MIC) and minimum bactericidal concentration $(\mathrm{MBC})$ values. The result indicated that the highest inhibition zone $(11 \mathrm{~mm})$ was presented in ethanolic pods extract against multidrug resistance Klebsiella pneumoniae. The lowest MIC value of $0.1 \mathrm{mg} / \mathrm{mL}$ was obtained from branch extracted with ethanol against colistin resistant Pseudomonas aeruginosa. The lowest MBC values of $1.6 \mathrm{mg} / \mathrm{mL}$ were obtained when using $C$. umbellatum leaves extracted with methanol against all test antibiotic-resistant bacteria. This is the first report presented C. umbellatum extracts have the potential to eliminate antibiotic-resistant bacteria in patients. These findings show the antibacterial effect of C. umbellatum.
\end{abstract}

\section{Introduction}

Antibiotic-resistant bacteria are a consequence of improper and/or overuse of antibiotics (Naeim et al., 2020) which as the main causes of human death worldwide in the hospital (Abadi et al., 2019). Many antibiotic groups that bacteria were resisted such as $\beta$ lactams, aminoglycosides, ulfonamides, and fluoroquinolones (Huai et al., 2019). Some of the most lifethreatening antibiotic-resistant bacterial strains with severe human implications worldwide are Pseudomonas aeruginosa, Acinetobacter baumannii (Abadi et al., 2019), Klebsiella pneumonia, Escherichia coli (Gregova and Kmet, 2020 ), Staphylococcus aureus (MRSA) (Bhattacharya, 2014), non-typhoidal Salmonella, Mycobacterium tuberculosis (Prestinaci et al., 2015), Stenotrophomonas maltophilia (Ç1kman et al., 2016), Enterococcus faecalis (Miller et al., 2014), Proteus mirabilis (Tumbarello et al., 2012), and Burkholderia pseudomallei (Bugrysheva et al., 2017). The finding for new drug sources to treat disease infected by antibiotic-resistant bacteria is required.

Medicinal plants are rich in a numerous variety of active compounds which have as antimicrobial properties such as berberine, piperine, eugenol, alicin, catechin, curcumin, saponins, tannins, alkaloids, alkenyl phenols, glycoalkaloids, flavonoids, sesquiterpenes lactones, terpenoids, and phorbol esters (Abdallah, 2011; Khameneh et al., 2019). The quinones from Lawsonia inermis had an antimicrobial activity against P. aeruginosa (Habbal et al., 2011). Hypericin from Hypericum perforatum, had general antimicrobial properties activity against methicillin-resistant and methicillin-sensitive Staphylococcus (Bahmani et al., 2019). PLR9 isolated from endophytic fungus Aspergillus neobridgeri shows antimicrobial activity against multi-drug resistant bacteria (Sadrati et al., 2020). Tannins isolated from the Pimenta dioica leaves show antimicrobial activity against methicillin resistant $S$. aureus (Al-Harbi et al., 2017). The aqueous extract of 
Lannea fruticosa showed the highest inhibition zone activity against both $P$. aeruginosa and $P$. mirabilis which was $20 \mathrm{~mm}$ and $19.5 \mathrm{~mm}$, respectively (Kidane et al., 2019).

Cathormion umbellatum (Vahl) Kosterm is a flowering plant in the legume family, Fabaceae which belongs to the mimosoid clade of the subfamily Caesalpinioideae. C. umbellatum is Thai mimosaceous plants that contained high antioxidant activity and can be stimulated white blood cell proliferation (Tunsaringkarn et al., 2014). Only antibacterial activity of C. umbellatum extracted with ethanol against E. coli was reported (Ramli, 2010). The determination of antibacterial activity against antibiotic-resistant bacteria has still lacked. Therefore, the aim of this study was to determine the antibacterial activity of C. umbellatum extracts against seven antibiotic-resistant bacteria collected from the Roi Et Hospital, Thailand.

\section{Materials and Methods}

Chemicals and reagents

Ethanol and methanol were purchased from QRëC ${ }^{\mathrm{TM}}$ (New Zealand). Dimethyl sulfoxide was purchased from Sigma-Aldrich (USA). Nutrient broth and bacterial agar were purchased from HiMedia (India). Iodonitrotetrazolium chloride was purchased from G-Biosciences (USA).

\section{Plant materials and extraction}

The fresh branch, leaves and pods of C. umbellatum were collected from Tha Muang Community, Tha Muang sub district, Selaphum District, Roi Et Province, Thailand. All plant samples were dried using hot air oven (POL-EKO-APARATURA company, Wodzisław Śląski, Poland) at $50^{\circ} \mathrm{C}$ for 48 hours before were grounded into powder. The plant powder was extracted with ethanol and methanol with shaking for 3 hours and then filtered and evaporated using a rotary vacuum evaporator (BÜCHI Labortechnik AG, Switzerland). The percent yield was calculated (Rattanasuk and Phiwthong, 2021). The plant extracts were adjusted the final concentration to $500 \mathrm{mg} / \mathrm{mL}$ using dimethyl sulfoxide.

\section{Antibacterial activity determination}

The antibacterial activity of the C. umbellatum extracts was tested against seven antibiotic-resistant bacteria including A. baumannii, S. maltophilia, E. faecalis, B. pseudomallei, P. mirabilis, multidrug resistance $K$. pneumoniae, colistin resistant $P$. aeruginosa. The active bacterial cultures were adjusted the cell concentration at $\mathrm{OD}_{600}$ to 0.1 before used.

The antibacterial activity of C. umbellatum extract was primary determined using disc diffusion assay (Boon- gapim et al., 2021; Malaka et al., 2018). Ten microliters of each C. umbellatum extract $(500 \mathrm{mg} / \mathrm{mL}$ ) was dropped onto the center of the paper disc. The dimethyl sulfoxide was used as a negative control. The bacterial culture plates were incubated at $37^{\circ} \mathrm{C}$ for 24 hours. The inhibition zone formation around the paper disc indicated as antibacterial activity of C. umbellatum extracts were measured.

The minimum inhibitory concentration (MIC) and minimum bactericidal concentration (MBC) values of $C$. umbellatum extracts were determined using a broth microdilution and colorimetric assay (Rattanasuk and Phiwthong, 2020). The C. umbellatum extracts which presented the inhibition zone from the previous part were 2 -fold serial diluted in a 96-well plate containing NB. The 96-well bacterial culture plates were incubated at $37^{\circ} \mathrm{C}$ for 24 hours. The iodonitrotetrazolium chloride $(4 \mathrm{mg} / \mathrm{mL})$ solution was added into each well of the $96-$ well bacterial culture plate and then incubated at $37^{\circ} \mathrm{C}$ for 1 hour. The MIC was referred to as the lowest concentration of the C. umbellatum extract that can inhibit bacterial growth. The MBC was considered as the lowest concentration of $C$. umbellatum extract that can eliminate the bacteria that did not produce a color change after the addition of iodonitrotetrazolium chloride (Dzotam et al., 2016).

\section{Results}

Percent yield and inhibition zone

The result of percent yield indicated that the highest percent yields at $15.9 \%$ was obtained when used the $C$. umbellatum leaves extracted with methanol, followed by pods extracted with methanol (13.3\%) and leaves extracted with ethanol $(11.7 \%)$, respectively. The lowest percent yields at $4.9 \%$ was found in branch extracted with ethanol.

The result of disc diffusion assay indicated that the highest inhibition zone at $11 \mathrm{~mm}$ was presented in ethanolic pods extract against multidrug resistance $K$. pneumoniae, followed by pods extracted with ethanol $(10 \mathrm{~mm})$, branch extracted with ethanol $(9.5 \mathrm{~mm})$ and leave extracted with methanol $(9 \mathrm{~mm})$ against $B$. pseudomallei, $P$. mirabilis and colistin resistant $P$. aeruginosa, respectively (Table I).

\section{MIC and $M B C$ values}

The results indicated that the lowest MIC value of 0.1 $\mathrm{mg} / \mathrm{mL}$ against colistin resistant $P$. aeruginosa was obtained from branch extracted with ethanol followed by $0.1 \mathrm{mg} / \mathrm{mL}$ was obtained from leave extracted with methanol against $P$. mirabilis, pods and leave extracted with methanol against B. pseudomallei $(0.4 \mathrm{mg} / \mathrm{mL})$, respectively (Table II). The lowest MBC values of 1.6 $\mathrm{mg} / \mathrm{mL}$ were obtained when using C. umbellatum leaves 


\begin{tabular}{|c|c|c|c|c|c|c|}
\hline \multicolumn{7}{|c|}{ Table I } \\
\hline \multicolumn{7}{|c|}{ Inhibition zone (mm) } \\
\hline & \multicolumn{2}{|c|}{ Pod } & \multicolumn{2}{|c|}{ Leaf } & \multicolumn{2}{|c|}{ Branch } \\
\hline & Ethanol & Methanol & Ethanol & Methanol & Ethanol & Methanol \\
\hline A. baumannii & 7 & 7 & 6.5 & 7 & 7.5 & 6.6 \\
\hline S. maltophilia & 7.5 & 7.5 & 6.5 & 7 & 7 & 7.5 \\
\hline E. faecalis & 7 & 8 & 8 & 7 & 8.5 & 7 \\
\hline B. pseudomallei & 10 & 7.5 & 6.5 & 7.5 & 7.5 & 6.5 \\
\hline P. mirabilis & 7 & 8 & 8 & 8 & 9.5 & 6.5 \\
\hline Multidrug resistant K. pneumoniae & 11 & 7.5 & 7.5 & 8 & 8 & 7 \\
\hline Colistin resistant $P$. aeruginosa & 7.5 & 7.5 & 8 & 9 & 7.5 & 8 \\
\hline
\end{tabular}

\begin{tabular}{|c|c|c|c|c|c|c|}
\hline \multicolumn{7}{|c|}{ Table II } \\
\hline \multicolumn{7}{|c|}{ Minimum inhibitory concentrations and minimal bactericidal concentration } \\
\hline \multicolumn{7}{|c|}{ Minimum inhibitory concentrations $(\mathrm{mg} / \mathrm{mL})$} \\
\hline & \multicolumn{2}{|c|}{ Pod } & \multicolumn{2}{|c|}{ Leaf } & \multicolumn{2}{|c|}{ Branch } \\
\hline & Ethanol & Methanol & Ethanol & Methanol & Ethanol & Methanol \\
\hline A. baumannii & 0.8 & 0.8 & 0.8 & 0.8 & 1.6 & 1.6 \\
\hline S. maltophilia & 0.8 & 0.8 & 0.8 & 0.8 & 3.1 & 3.1 \\
\hline E. faecalis & 0.8 & 0.8 & 1.6 & 0.2 & 3.1 & 3.1 \\
\hline B. pseudomallei & 0.4 & 0.2 & 0.4 & 0.8 & 1.6 & 1.6 \\
\hline P. mirabilis & 0.8 & 0.8 & 0.8 & 0.1 & 1.6 & 3.1 \\
\hline Multidrug resistant K. pneumoniae & 0.8 & 1.6 & 1.6 & 0.8 & 3.1 & 3.1 \\
\hline Colistin resistant $P$. aeruginosa & 1.6 & 1.6 & 0.8 & 0.8 & 0.1 & 1.6 \\
\hline \multicolumn{7}{|c|}{ Minimal bactericidal concentration $(\mathrm{mg} / \mathrm{mL})$} \\
\hline A. baumannii & 1.6 & 3.1 & 3.1 & 1.6 & 3.1 & 3.1 \\
\hline S. maltophilia & 1.6 & 1.6 & 1.6 & 1.6 & 6.3 & 6.3 \\
\hline E. faecalis & 1.6 & 1.6 & 3.1 & 1.6 & 6.3 & 12.5 \\
\hline B. pseudomallei & 1.6 & 1.6 & 1.6 & 1.6 & 3.1 & 3.1 \\
\hline P. mirabilis & 3.1 & 1.6 & 1.6 & 1.6 & 3.1 & 6.3 \\
\hline Multidrug resistant K. pneumoniae & 3.1 & 6.3 & 3.1 & 1.6 & 6.3 & 6.3 \\
\hline Colistin resistant $P$. aeruginosa & 3.1 & 3.1 & 1.6 & 1.6 & 3.1 & 3.1 \\
\hline
\end{tabular}

extracted with methanol against all test antibioticresistant bacteria, leaves extracted with ethanol against S. maltophilia, B. pseudomallei P. mirabilis and colistin resistant $P$. aeruginosa, pods extracted with ethanol against $A$. baumannii, S. maltophilia, E. faecalis and $B$. pseudomallei, pods extracted with methanol against $S$. maltophilia, E. faecalis, B. pseudomallei and P. mirabilis. The highest MBC value of $12.5 \mathrm{mg} / \mathrm{mL}$ was found in branch extracted with methanol against E. faecalis.

\section{Discussion}

C. umbellatum shows antibacterial and antioxidant activity (Tunsaringkarn et al., 2014). It has been found that the ethanolic branch extract was presented that the lowest MIC value of $0.1 \mathrm{mg} / \mathrm{mL}$ against CoR-PA and methanolic leave extract was showed the lowest MBC values of $1.6 \mathrm{mg} / \mathrm{mL}$ against all test antibiotic-resistant bacteria. The mechanism of action is not clear.
The are no reports about that antibacterial activity $C$. umbellatum extract against antibiotic-resistant bacteria. Only a report about the ethanolic extract of $C$. umbellatum leaves has a MIC value of $0.8 \mathrm{mg} / \mathrm{mL}$ against $S$. aureus, B. subtilis and E. coli is presented (Ramli, 2010). The C. umbellatum extract is presented high antibiotic potential activity due to lower MIC values compared with using antibiotics (KawamuraSato et al., 2000) or Lannea fruticose (Kidane et al., 2019), Tanacetum vulgare and Bidens sulphurea extract (Chiavari -Frederico et al., 2020). The present study indicates that the MIC values of $C$. umbellatum pods and leave extracted with methanol against $B$. pseudomallei are lower than MIC values of amoxicillin-clavulanic acid (8 $\mathrm{mg} / \mathrm{mL})$, ceftazidime $(8 \mathrm{mg} / \mathrm{mL})$, imipenem $(2 \mathrm{mg} /$ $\mathrm{mL})$, meropenem $(2 \mathrm{mg} / \mathrm{mL})$, doxycycline $(2 \mathrm{mg} / \mathrm{mL})$, tetracycline $(8 \mathrm{mg} / \mathrm{mL})$, chloramphenicol $(8 \mathrm{mg} / \mathrm{mL})$ and trimethoprim-sulfamethoxazole $(4 \mathrm{mg} / \mathrm{mL})$ (Karatuna et al., 2020).

The MBC values of C. umbellatum extract against $A$. 
baumannii from this research are higher than MBC of colistin $(0.5 \mathrm{mg} / \mathrm{L})$ and sulbactam $(32 \mathrm{mg} / \mathrm{L})$ (Thamlikitkul and Tiengrim, 2014). The Litsea cubeba oil exhibits a strong inhibitory effect with MBC value of $0.1 \%(\mathrm{v} / \mathrm{v})$ against S. maltophilia (Zhang et al., 2020). Red honey and white honey have MBC values of $30.4-62.5 \%$ and $60.7-75 \%$ (v/v) against multidrug resistant bacteria (Wasihun and Kasa, 2016). Proanthocyanidins and flavonoids glycoside are potential phytochemical groups content of C. umbellatum extracts which act as an antibacterial reagent (Ramli, 2010). Proanthocyanidins are phytochemicals found from C. umbellatum which synthesized from tannin and are presented various biological activities including antioxidant, anticancer, antidiabetic, neuroprotective, and antimicrobial activity (Rauf et al., 2019). The proanthocyanidins of Dalbergia monetaria extracts present the antibacterial activity against methicillin sensitive $S$. aureus, methicillinresistant $S$. aureus and $P$. aeruginosa with MIC values of 64, 64 and $32 \mu \mathrm{g} / \mathrm{mL}$, respectively (de Moura et al., 2020). The curcuminoids have an antimicrobial activity against E. faecalis with MBC of $50 \mu \mathrm{g} / \mathrm{mL}$ (Suttipalin et al., 2014).

\section{Conclusion}

The present study shows the antimicrobial activity of $C$. umbellatum against antibiotic-resistant bacteria.

\section{Financial Support}

This research project was supported by Roi Et Rajabhat University grant No. 2557A15062001

\section{Conflict of Interest}

Authors declare no conflict of interest

\section{References}

Abadi ATB, Rizvanov AA, Haertlé T, Blatt NL. World Health Organization report: Current crisis of antibiotic resistance. Bio Nano Sci. 2019; 9: 778-88.

Abdallah EM. Plants: An alternative source for antimicrobials. J Appl Pharm Sci. 2011; 1: 16-20.

Al-Harbi R, Al-wegaisi R, Moharram F, Shaaban M, Abd ElRahman O. Antibacterial and anti-hemolytic activity of tannins from Pimenta dioica against methicillin resistant Staphylococcus aureus. Bangladesh J Pharmacol. 2017; 12: 6368.

Bahmani M, Taherikalani M, Khaksarian M, Rafieian-Kopaei M, Ashrafi B, Nazer M, Soroush S, Abbasi N, Rashidipour M. The synergistic effect of hydroalcoholic extracts of Origanum vulgare, Hypericum perforatum and their active components carvacrol and hypericin against Staphylococcus aureus. Future Sci. 2019; 2019.

Bhattacharya PK. Emergence of antibiotic-resistant bacterial strains, methicillin-resistant Staphylococcus aureus, extended spectrum beta lactamases, and multi-drug resistance is a problem similar to global warming. Rev Soc Bras Med Trop. 2014; 47: 815-16.

Boongapim R, Ponyaim D, Phiwthong T, Rattanasuk S. In vitro antibacterial activity of Capparis sepiaria L. against human pathogenic Bacteria. Asian J Plant Sci. 2021; 20: 102-18.

Bugrysheva JV, Sue D, Gee JE, Elrod MG, Hoffmaster AR, Randall LB, Chirakul S, Tuanyok A, Schweizer HP, Weigel LM. Antibiotic resistance markers in Burkholderia pseudomallei strain Bp1651 identified by genome sequence analysis. Antimicrob Agents Chemother. 2017; 61: e00010-17.

Chiavari-Frederico MO, Barbosa LN, Carvalho dos Santos I, Ratti da Silva G, Fernandes de Castro A, de Campos Bortolucci W, Barboza LN, Campos CFdAA, Gonçalves JE, Menetrier JV. Antimicrobial activity of Asteraceae species against bacterial pathogens isolated from postmenopausal women. PLoS One. 2020; 15: e0227023.

Çıkman A, Parlak M, Bayram Y, Güdücüoğlu H, Berktaş M. Antibiotics resistance of Stenotrophomonas maltophilia strains isolated from various clinical specimens. Afr Health Sci. 2016; 16: 149-52.

de Moura PHB, de Sousa AA, Porzel A, Wessjohann LA, Leal ICR, Martins RCC. Characterization of antibacterial proanthocyanidins of dalbergia monetaria, an Amazonian medicinal plant, by UHPLC-HRMS/MS. Planta Med. 2020; 86: 858-66.

Dzotam JK, Touani FK, Kuete V. Antibacterial activities of the methanol extracts of Canarium schweinfurthii and four other Cameroonian dietary plants against multi-drug resistant Gram-negative bacteria. Saudi J Biol Sci. 2016; 23: 565-70.

Gregova G, Kmet V. Antibiotic resistance and virulence of Escherichia coli strains isolated from animal rendering plant. Sci Rep. 2020; 10: 1-7.

Habbal O, Hasson S, El-Hag A, Al-Mahrooqi Z, Al-Hashmi N, Al-Bimani Z, Al-Balushi M, Al-Jabri A. Antibacterial activity of Lawsonia inermis Linn (Henna) against Pseudomonas aeruginosa. Asian Pac J Trop Biomed. 2011; 1: 173-76.

Huai W, Ma Q-B, Zheng J-J, Zhao Y, Zhai Q-R. Distribution and drug resistance of pathogenic bacteria in emergency patients. World J Clin Cases. 2019; 7: 3175.

Karatuna O, Dance D, Matuschek E, Åhman J, Turner P, Hopkins J, Amornchai P, Wuthiekanun V, Cusack T-P, Baird R. Burkholderia pseudomallei multi-centre study to establish EUCAST MIC and zone diameter distributions and epidemiological cut-off values. Clin Microbiol Infect. 2021; 27: 736-41.

Kawamura-Sato K, Iinuma Y, Hasegawa T, Horii T, Yamashino T, Ohta M. Effect of subinhibitory concentrations of macrolides on expression of flagellin in Pseudomonas aeruginosa and Proteus mirabilis. Antimicrob Agents Chemother. 2000; 44: 2869-72.

Khameneh B, Iranshahy M, Soheili V, Bazzaz BSF. Review on plant antimicrobials: A mechanistic viewpoint. Antimicrob Resist Infect Control. 2019; 2019. 
Kidane A, Rezene A, G/Hannes O, G/Michael S, Mehreteab S, Jyoti SMJ, Andom H. Antibacterial activities of selected medicinal plants against multi-drug resistant bacteria isolated from urine samples of catheterized patients. Clin Microbiol. 2019; 2019.

Malaka M, Yanti N, Hartati R, Sahidin I. Radical scavenging and antibacterial activity of phenolic compounds from Anacardium occidentale L. stem barks from South East Sulawesi-Indonesia. Indian J Pharm Sci. 2018; 80: 143-49.

Miller WR, Munita JM, Arias CA. Mechanisms of antibiotic resistance in enterococci. Expert Rev Anti Infect Ther. 2014; 12: $1221-36$

Naeim H, El-Hawiet A, Rahman RAA, Hussein A, El Demellawy MA, Embaby AM. Antibacterial activity of Centaurea pumilio L. root and aerial part extracts against some multidrug resistant bacteria. BMC Complement Med Ther. 2020; 20: $1-13$.

Prestinaci F, Pezzotti P, Pantosti A. Antimicrobial resistance: A global multifaceted phenomenon. Pathog Glob Health. 2015; 109: 309-18.

RamliS. Bioactivity evaluations and phytochemical characterizations of ethanolic extracts from selected mimosaceous plants endemic to Thailand. Chulalongkorn University. 2010.

Rattanasuk S, Phiwthong T. Evaluation of the antibacterial activity of Spathiphyllum wallisii extracts against human pathogenic bacteria. Pakistan J Biol Sci. 2020; 23: 1436-41.

Rattanasuk S, Phiwthong T. A New potential source of antipathogenic bacterial substances from Zamioculcas zamiifolia (Lodd.) Engl. extracts. Pakistan J Biol Sci. 2021; 24: 235-40.

Rauf A, Imran M, Abu-Izneid T, Iahtisham Ul H, Patel S, Pan
X, Naz S, Sanches Silva A, Saeed F, Rasul Suleria HA. Proanthocyanidins: A comprehensive review. Biomed Pharmacother. 2019; 116: 108999.

Sadrati N, Zerroug A, Demirel R, Bakli S, Harzallah D. Antimicrobial activity of secondary metabolites produced by Aspergillus neobridgeri isolated from Pistacia lentiscus against multi-drug resistant bacteria. Bangladesh J Pharmacol. 2020; 15: 82-85.

Suttipalin S, Suttimas Y, Nirascha C. Effect of purified curcuminoids on Enterococcus faecalis and its biofilm. Int J Clin Prev Dent. 2014; 10: 71-78.

Thamlikitkul V, Tiengrim S. In vitro activity of colistin plus sulbactam against extensive-drug-resistant Acinetobacter baumannii by checkerboard method. J Med Assoc Thai. 2014; 97: S1-S6.

Tumbarello M, Trecarichi EM, Fiori B, Losito AR, D'Inzeo T, Campana L, Ruggeri A, Di Meco E, Liberto E, Fadda G. Multidrug-resistant Proteus mirabilis bloodstream infections: Risk factors and outcomes. Antimicrob Agents Chemother. 2012; 56: 3224-31.

Tunsaringkarn T, Suwansaksri J, Rungsiyothin A, Palasuwan A. Cell proliferation activities in vitro model of Thai mimosaceous extracts. J Chem Pharm Res. 2014; 6: 507-11.

Wasihun AG, Kasa BG. Evaluation of antibacterial activity of honey against multidrug resistant bacteria in Ayder Referral and Teaching Hospital, Northern Ethiopia. Springer Plus. 2016; 5: 1-8.

Zhang Y, Wei J, Chen H, Song Z, Guo H, Yuan Y, Yue T. Antibacterial activity of essential oils against Stenotrophomonas maltophilia and the effect of citral on cell membrane. LWT. 2020; 117: 108667. 